\title{
ENERGETIC DEMANDS DURING INCUBATION AND CHICK REARING IN A UNIPARENTAL AND A BIPARENTAL SHOREBIRD BREEDING IN THE HIGH ARCTIC
}

\author{
Ingrid Tulp, ${ }^{1,2,10}$ Hans Schekkerman, ${ }^{2,3}$ Leo W. Bruinzeel, ${ }^{2,4}$ JoOp Jukema, $^{2,5}$ \\ G. Henk Visser, $6,7,11$ and Theunis Piersma ${ }^{8,9}$ \\ ${ }^{1}$ Institute for Marine Resources and Ecosystem Studies (IMARES), P.O. Box 68, 1970 AB IJmuiden, The Netherlands; \\ ${ }^{2}$ Working Group International Waterbird and Wetland Research (WIWO), P.O. Box 925, 3700 AX Zeist, The Netherlands; \\ ${ }^{3}$ Dutch Centre for Avian Migration and Demography, Netherlands Institute of Ecology (NIOO-KNAW), P.O. Box 40, \\ 6666 ZG Heteren, The Netherlands; \\ ${ }^{4}$ Altenburg \& Wymenga Ecological Consultants, P.O. Box 32, 9269 ZR Veenwouden, The Netherlands; \\ ${ }^{5}$ Haerdawei 62, 8854 AC Oosterbierum, The Netherlands; \\ ${ }^{6}$ Centre for Isotope Research, University of Groningen Nijenborgh 4, 9747 AG Groningen, The Netherlands; \\ ${ }^{7}$ Behavioural Biology, University of Groningen, P.O. Box 14, 9750 AA Haren, The Netherlands; \\ ${ }^{8}$ Department of Marine Ecology and Evolution, Royal Netherlands Institute for Sea Research (NIOZ), P.O. Box 59, \\ 1790 AB Den Burg, Texel, The Netherlands; and \\ ${ }^{9}$ Animal Ecology Group, Centre for Ecological and Evolutionary Studies, University of Groningen, P.O. Box 14, 9750 AA Haren, The Netherlands
}

\begin{abstract}
Rearing of young has long been considered the energetically most demanding phase of the avian breeding cycle. Arctic-breeding shorebirds expend large amounts of energy during breeding. Because they are too small to carry sufficient stores to sit out the incubation period, they regularly interrupt incubation to feed and still can run short of energy, particularly in species in which one adult takes care of the eggs and chicks alone (uniparental). We measured daily energy expenditure (DEE) and time budgets during incubation and chick rearing in the smallest uniparental Arctic shorebird, the Little Stint (Calidris minuta). Daily energy expenditure decreased with increasing temperature but did not differ between the incubation and chick-rearing periods. Because of the increase in potential foraging time from incubation to the chick-rearing phase, the foraging intake rate required to balance the budget dropped by two-thirds. To evaluate the effect of uniparental care on energy budgets, we also measured DEE in the Dunlin (C. alpina), a sympatric congener in which both parents incubate but the female deserts the brood after hatching. Daily energy expenditure decreased with temperature, was the same during incubation and chick rearing, and was higher in males. Our results are discussed in relation to the timing of breeding of Arctic shorebirds with different systems of parental care. Received 31 October 2007, accepted 28 September 2008.
\end{abstract}

Key words: Calidris alpina, C. minuta, daily energy expenditure, doubly labeled water, Dunlin, Little Stint, parental care system, tundra.

\section{Requerimientos Energéticos Durante la Incubación y Crianza de los Pichones en un Ave Playera Uniparental y una Biparental que se Reproducen en el Ártico}

RESUMEN.-Se ha considerado que la crianza de los pichones es la fase del ciclo reproductivo de las aves que más energía requiere. Las aves playeras que se reproducen en el Ártico gastan grandes cantidades de energía durante la reproducción. Debido a que son demasiado pequeñas para cargar suficientes reservas para permanecer quietas durante el período de incubación, éstas regularmente interrumpen la incubación para alimentarse y aún así pueden terminar sin energía, particularmente en especies en las que sólo un adulto cuida de los huevos y los pichones (cuidado uniparental). Medimos el gasto diario de energía (GDE) y los presupuestos de tiempo durante la incubación y la crianza de los pichones en Calidris minuta, el ave playera ártica de menor tamaño. El GDE disminuyó al aumentar la temperatura, pero no difirió entre los períodos de incubación y de crianza de los pichones. Debido al incremento en el tiempo potencial de forrajeo desde la fase de incubación a la de crianza de los pichones, la tasa de ingestión de alimento necesaria para

${ }^{10}$ E-mail: ingrid.tulp@wur.nl

${ }^{11}$ Deceased in 2007.

The Auk, Vol. 126, Number 1, pages 155-164. ISSN 0004-8038, electronic ISSN 1938-4254. @ 2009 by The American Ornithologists' Union. All rights reserved. Please direct all requests for permission to photocopy or reproduce article content through the University of California Press's Rights and Permissions website, http://www.ucpressjournals. com/reprintInfo.asp. DOI: 10.1525/auk.2009.07181 
balancear el presupuesto disminuyó en dos tercios. Para evaluar el efecto del cuidado uniparental sobre los presupuestos energéticos, también medimos el GDE en C. alpina, un congénere simpátrico en el que los dos padres incuban pero la hembra deserta la nidada después de la eclosión. El GDE disminuyó con la temperatura, fue igual durante la incubación y la crianza de los pichones, y fue mayor en los machos. Nuestros resultados se discuten en relación con el momento en que sucede la reproducción en aves playeras del Ártico con diferentes sistemas de cuidado parental.

A BIRD'S DECISION of when to breed is likely to be shaped by both its chicks' needs and the energetic requirements of the parents during the prelaying, incubation, and chick-rearing phases (Perrins 1970, Drent 2006). This is especially so in strongly seasonal environments, in which the "reproductive window" is short because of highly dynamic changes in weather and food availability. Generally, the period of feeding young is regarded as one of the energetically most demanding phases in the annual cycle of birds (Drent and Daan 1980, Weathers and Sullivan 1993). In species that feed their young, numerous provisioning flights from the food source to the chicks result in higher energy expenditure in the chick-rearing than in the incubation period (Bryant and Tatner 1991). Although incubation has long been considered an energetically inexpensive activity, recent work has shown that incubation is costly (Tinbergen and Williams 2002, de Heij 2006), especially for Arctic-breeding birds (Piersma et al. 2003). Although energy expenditure in breeding terrestrial birds is, on average, higher during brood rearing than during incubation, there are many species in which expenditure in the two phases is similar (Tinbergen and Williams 2002).

Unless they can make use of endogenously stored nutrients, breeding birds must balance their energy expenditure with food uptake, which takes time and may compete with other important activities like incubation, brooding, or guarding of young. Comparison of energetic demands on birds during different parts of the breeding cycle is, therefore, incomplete without also considering time budgets. A measure that integrates both aspects is the energy intake rate during foraging that is required to balance the energy budget, equal to the ratio between daily energy expenditure (DEE) and daily (potential) foraging time.

The relative magnitude of the energetic demand during incubation and chick rearing is likely to vary between bird species according to the developmental mode of their young and the system of parental care. In many species in which incubation is performed by one sex only (uniparental), the parent regularly leaves its clutch to feed and, therefore, must frequently rewarm cooled eggs (Tulp and Schekkerman 2006). This will require greater energy expenditure than an incubation pattern in which the optimal clutch temperature is maintained for prolonged periods (Williams 1996, Tinbergen and Williams 2002). Simultaneously, the time available for foraging is restricted by the need to incubate the eggs and is generally more limited in uniparental incubators than in biparental species in which both parents share incubation (e.g., in shorebirds $13-19 \%$ vs. $~ 50 \%$ of the day; Norton 1972, Cartar and Montgomerie 1987, Cresswell et al. 2003, Tulp and Schekkerman 2006).

The chick-rearing period may well be less demanding for species with precocial and self-feeding chicks, like shorebirds, than for species that deliver food to their young. Guarding of precocial chicks may entail little extra cost for parents, given that it can be combined with foraging for themselves, but the regular brooding required by many young precocial chicks will, to some extent, limit parental foraging time. However, because field measurements of energy expenditure during brood rearing have been made almost exclusively in birds that feed their young (reviewed in Tinbergen and Williams 2002), and only in a single precocial species (Bryant and Tatner 1991), the net effect of developmental mode on energetic demands on parent birds remains a matter of conjecture.

We investigated how the incubation and chick-rearing phases compare energetically by measuring DEE and time budgets in the Little Stint (Calidris minuta), a small precocial shorebird with uniparental incubation that breeds in the High Arctic. Its small size (mean body mass $29 \mathrm{~g}$ ) is expected to exacerbate the energetic demands posed by the Arctic climate (e.g., by a strong dependence of DEE on temperature). To explore the effect of parental role division on energetic demands, we also collected DEE measurements in the closely related Dunlin (Calidris alpina), a slightly larger (53g) biparental species that nests in the same area.

\section{Methods}

Study area and species. - Data were collected during June to early August of 1996 and 2000-2002 at Medusa Bay, on the Taimyr peninsula, Siberia $\left(73^{\circ} 20^{\prime} \mathrm{N} 80^{\circ} 30^{\prime} \mathrm{E}\right)$. At this latitude, there is continuous daylight throughout the breeding period. The habitat consists of Arctic tundra (Chernov 1985), with a rolling relief between 0 and $50 \mathrm{~m}$ above sea level, and scattered stony ridges. Vegetation consisted of mosses, lichens, and grasses generally $<10 \mathrm{~cm}$ in height, and a significant portion of the soil was bare. Wet valleys were covered with sedges and low polar willow (Salix spp.).

Female Little Stints produce two clutches; the first is usually attended by the male and the second by the female. Consequently, each parent takes care of a clutch and brood alone (Hildén 1978, Tulp et al. 2002). Nests of Little Stints are generally located in or close to grass or sedge fields, often in valleys or on south-facing slopes. Nest cups are lined with a thick layer (mean $=2.9 \pm 1.5$ [SD] cm; $n=60$ ) of dry willow leaves (Tulp 2007). In Dunlin, male and female share incubation duties equally, but females desert the brood at hatching (Cramp and Simmons 1983). Dunlin nests are found on the higher part of slopes and on flat ridge tops, in relatively dry, frost-boiled tundra. The nest-cup lining consists of willow leaves, lichens, sedges, and grasses (mean $=1.8 \pm 0.8 \mathrm{~cm} ; n=$ 22; Tulp 2007). Despite the differences in breeding microhabitat, the two species often breed in proximity. Dunlin started incubating in late June (median dates 19, 17, and 24 June in 2000-2002; Schekkerman et al. 2004). Little Stints started slightly later and incubated over a longer period because of their double-clutch system (median clutch completion dates 29 June, 25 June, and 1 July in 2000-2002).

Weather data.-In 2000, data on precipitation $\left(\mathrm{mm} \mathrm{day}^{-1}\right)$ and wind $\left(\mathrm{m} \mathrm{s}^{-1}\right)$ were provided by the meteorological station in Dikson, $18 \mathrm{~km}$ north of the study area. In 2001 and 2002, all weather 
data, and in 1996 and 2000 air temperature, were recorded every half hour at our study site using an automated weather station. Air temperature was recorded in the shade at a height of $1 \mathrm{~m}$, and wind speed at a height of $10 \mathrm{~m}$. Daily mean temperature varied between $0^{\circ} \mathrm{C}$ and $15^{\circ} \mathrm{C}$ and between $0^{\circ} \mathrm{C}$ and $20^{\circ} \mathrm{C}$ in June and July, respectively. The amount of precipitation was generally low, apart from 2002, when total rainfall in June-August was $130 \mathrm{~mm}$.

Capturing birds.-Nests were located by intensive searching during the laying and incubation periods. All nests in which the adults were subjected to energy expenditure measurements contained the set of four eggs characteristic of the species. Incubating birds were caught using small clap nets that were set up over the nest and released by the bird when it returned to the eggs. To avoid nest desertion, we caught birds only from the second week of incubation onward. Birds tending chicks were captured with the same clap net or with a mist net that was held between two observers and pulled over the approaching bird. In both cases, the adult was lured to the net by placing the chicks in a small cage. Birds were usually caught within 10 min after the first disturbance. They were tagged with metal rings and individual colored-ring combinations. Bill length was measured to the nearest $0.1 \mathrm{~mm}$ using calipers. Wing length (maximum chord, $1 \mathrm{~mm}$ ) was measured with a stopped ruler. Body mass was measured with Pesola spring balances (to $0.1 \mathrm{~g}$ ). Dunlin were sexed on the basis of plumage characteristics and size (Prater et al. 1977). Little Stints could not be reliably sexed on the basis of external dimensions or plumage.

Doubly labeled water measurements.-Measurements of $\operatorname{DEE}\left(\mathrm{kJ} \mathrm{day}^{-1}\right)$ were made in a variety of weather conditions, using the doubly labeled water (DLW) method (Lifson and McClintock 1966, Speakman 1997). In addition to the 30 measurements made in the present study, we also included three previously published measurements of incubating Little Stints collected at another site in Taimyr, Cape Sterlegov $\left(75^{\circ} 25^{\prime} \mathrm{N}, 89^{\circ} 08^{\prime} \mathrm{E}\right.$; Piersma et al. 2003). For 23 of the 33 measurements of Little Stints and 12 of the 20 measurements of Dunlin, we followed a two-sample protocol with both an initial and a final measurement of isotope concentrations. For the remaining measurements, we applied a singlesample protocol (Webster and Weathers 1989) and took only a final blood sample to minimize capture and handling stress and, thereby, reduce the risk of nest desertion or brood disruption (see Appendices).

All experimental birds were injected subcutaneously in the brood-patch area with a known quantity $(0.10-0.20 \mathrm{~mL})$ of DLW consisting of $32 \% \mathrm{D}_{2} \mathrm{O}$ and $68 \% \mathrm{H}_{2}{ }^{18} \mathrm{O}$. Birds subjected to the twosample protocol were kept in a bag for an equilibration period of $1 \mathrm{~h}$ while their chicks were kept warm using a water bottle. Eggs were covered to slow cooling. After $1 \mathrm{~h}$, during which biometrical measurements were taken, four to six blood samples $(10-15 \mu \mathrm{L})$ were collected from the brachial vein in the wing into glass capillary tubes, which were flame-sealed within minutes. Adults and chicks were subsequently released together. Birds subjected to the single-sample protocol were released immediately after injection and biometric measurements. Little Stints were recaptured after $23-28 \mathrm{~h}($ mean $=24.5 \pm 1.1$ [SD] $\mathrm{h} ; n=33)$ and Dunlin after $23-32 \mathrm{~h}$ (mean $=24.8 \pm 1.8 \mathrm{~h} ; n=18)$ or $48 \mathrm{~h}(n=2)$, when a final set of blood samples and measurements were taken. Incubating birds were recaptured on the nest; chick-rearing birds were recaptured on or near their chicks after the brood had been relocated.
Initial isotope concentrations were measured directly in the initial blood samples taken in the two-sample protocol. For birds subjected to the single-sample protocol, initial concentrations were calculated from the amount injected and estimates of the size of the total body water pool. These estimates were based on a regression of initial isotope levels on body mass in birds in which a two-sample protocol was used. In three adults of each species and in each year, a set of blood samples was taken before injection of DLW to measure background isotope levels. The $\operatorname{ratios}{ }^{2} \mathrm{H} /{ }^{1} \mathrm{H}$ and ${ }^{18} \mathrm{O} /{ }^{16} \mathrm{O}$ in the blood samples were analyzed with a SIRA 9 isotope ratio mass spectrometer at the Centre for Isotope Research, Groningen, following procedures described in Visser and Schekkerman (1999). Analyses were done two or three times if the two measurements differed by $>2 \%$. The fraction body water was calculated with the isotope dilution method using the plateau values of the $\mathrm{H}_{2}{ }^{18} \mathrm{O}$ enrichments above the average background concentrations and the dose. We calculated $\mathrm{CO}_{2}$ production on the basis of equation 7.17 in Speakman (1997). We calculated DEE using an energy equivalent of $27.33 \mathrm{~kJ} \mathrm{~L}^{-1} \mathrm{CO}_{2}$ for a protein-rich diet (Gessaman and Nagy 1988). Energy density was estimated to be $39 \mathrm{~kJ} \mathrm{~g}^{-1}$ body mass (Ricklefs 1974; i.e., assuming that variation in body mass involves mainly variation in fat stores).

Multiple regression analysis was used to investigate the relationship between DEE and explanatory variables. Mean temperature and wind speed were averaged over the period between injection and recapture for every DLW measurement and incorporated in the model together with wing length, body mass, time in relation to the date of hatching (days), and the breeding phase (incubation or chick rearing). In Dunlin, effects of sex were tested as well.

Time budgets of Little Stint.-Incubation schedules in Little Stint were recorded from nest temperature measurements made with a small temperature probe $(2 \times 5 \mathrm{~mm}$; temperature range: -10 to $50^{\circ} \mathrm{C}$ ) positioned between the eggs and connected by a thin wire to a waterproof data logger (Tinytag, Gemini, Chichester, United Kingdom; Tulp and Schekkerman 2006). The loggers were covered with moss to avoid attracting predators. They were replaced after 11 days (when storage capacity was reached at 1-min recording intervals) or collected after the chicks had hatched or the nest was depredated. Start and end of incubation recesses were determined from graphs of temperature in relation to time. For further description of data handling, see Tulp and Schekkerman (2006).

Time budgets of Little Stints tending chicks were determined by visual observation, using a telescope from a slightly elevated observation point. Little Stint families with young chicks generally prefer short vegetation on low-lying sedge fields. Families show apparently undisturbed behavior at short distances (20$50 \mathrm{~m}$ in young broods and $100 \mathrm{~m}$ in older broods). Duration of brooding and nonbrooding bouts and the activity of the parent and chicks were registered to the nearest $10 \mathrm{~s}$. This was used to obtain age- and temperature-specific estimates of brooding and foraging time. Broods formed the statistical unit, because the alternation between brooding and feeding is highly synchronized among chicks of one brood. Total time minus time spent brooding constitutes the "potential foraging time" for the adult. Actual foraging time was determined by estimating the proportion of nonbrooding time that the parent spent foraging rather than engaging 
in other behaviors. Because of the often rapid alternation between feeding and vigilance or communication with chicks, this estimate has a limited precision of $10-20 \%$. Observations were made on six different broods in 2000, 2001, and 2002. Observation periods $(n=$ 40 ) were scattered throughout the $24 \mathrm{~h}$ of daylight and at all stages of chick development, from hatching to 17 days after, and totaled $60.9 \mathrm{~h}$ in bouts of $38-130 \mathrm{~min}$ (mean $=91 \pm 25 \mathrm{~min}$ ). Multiple regression was used to investigate the relationships between the proportion of time spent brooding and age, temperature, and time (e.g., whether it was day [0400-2200 hours], when light levels and temperatures are generally highest, or night [2200-0400 hours]). Proportions were logit-transformed before analysis.

We did not measure time budgets of incubating and broodrearing Dunlin. Nest temperatures do not reveal incubation schedules in this species, because Dunlin parents share incubation and overall nest attendance is close to 100\% (Norton 1972, Cresswell et al. 2003). Time-budget observations on Dunlin broods were precluded by their poor visibility in generally higher and denser vegetation, combined with more wary parents and crepuscular behavior of the chicks.

For Little Stint, the minimum metabolizable intake rate while foraging needed to balance energy intake with DEE (required intake rate, $I R_{f}$ ) was calculated as $I R_{f}=D E E$ / potential foraging time. To reflect the full variation in weather conditions encountered in the respective stages of the breeding cycle, we did this for each day of the incubation period (between start of incubation on the first and the last nest) and the chick-rearing period (between hatching of the first and the last nest) in 2000-2002 (Schekkerman et al. 2004), and averaged over all years. We calculated daily values of DEE and potential feeding time by inserting the measured temperatures into regression equations relating DEE and potential feeding time to temperature (derived from Tulp and Schekkerman [2006] for incubating birds, from our brood observations of chickrearing birds, assuming a chick age of 5 days).

\section{Results}

Daily energy expenditure in Little Stint and Dunlin.-Daily energy expenditure in Little Stint was negatively correlated with mean temperature over the period of measurement $(F=4.7, \mathrm{df}=1$ and 31, $P=0.038 ;$ Fig. 1 ). In a regression analyzing both phases simultaneously, body mass, wing length, days to hatching, mass change, and breeding phase had no significant effect on DEE (all $P>0.05$ ). The interaction term between breeding phase and temperature was not significant, which indicates that the slope for the relation between DEE and mean temperature did not differ between the two phases. On average, DEE in Little Stints was $156.3 \mathrm{~kJ} \mathrm{day}^{-1}$ (both phases combined; see Appendix 1). In breeding Dunlin, DEE was, on average, $231.4 \mathrm{~kJ} \mathrm{day}^{-1}$ and was not affected by body mass, wing length, days to hatching, mass change, and phase of the breeding cycle. Daily energy expenditure was negatively related to mean temperature $(F=10.65, \mathrm{df}=1$ and $19, P=0.005)$ and differed between the sexes (Fig. 2). Males had a significantly higher DEE than females $(F=22.0, \mathrm{df}=1$ and $19, P<0.001)$. Adding sex to the model before mean temperature gave the same result.

Time budgets of Little Stint.-D During incubation, Little Stints spent, on average, $18.8 \pm 7.7 \%$; $(n=197)$ or 4.4 h of each day away from the nest, with no variation caused by the stage of incubation

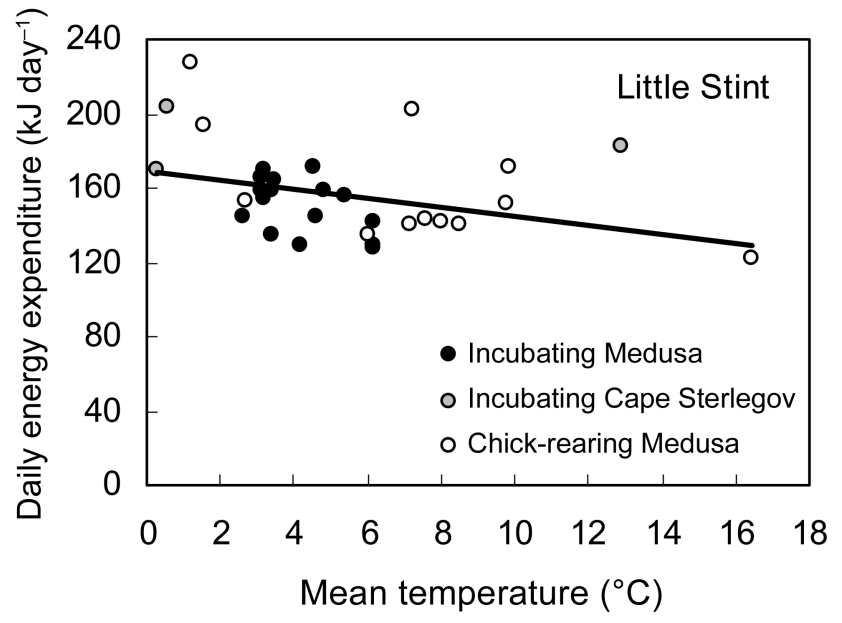

FIG. 1. Daily energy expenditure (DEE) in incubating and chick-rearing Little Stints as a function of the mean temperature over the measurement period. The three points collected at a different site are indicated with a different symbol. The line represents the overall significant regression line for DEE as a function of temperature. After correction for temperature, there was no difference in DEE between incubating and chick-rearing Little Stints.

(Tulp and Schekkerman 2006). Total recess time decreased slightly with increasing temperature from $5 \mathrm{~h} \mathrm{day}^{-1}$ at $0^{\circ} \mathrm{C}$ to $4 \mathrm{~h} \mathrm{day}^{-1}$ at $14^{\circ} \mathrm{C}$ (Tulp and Schekkerman 2006). Nonsystematic observations of birds during incubation recesses suggested that they use virtually all of this time for foraging, exhibiting noticeably faster movements than before breeding.

During the chick-rearing phase, potential and actual foraging time increased significantly with chick age and temperature (Table 1 and Fig. 3). Parents with chicks up to one week old ( $n=$ 28 ) spent, on average, $46.1 \pm 22.6 \%$ of their time brooding and

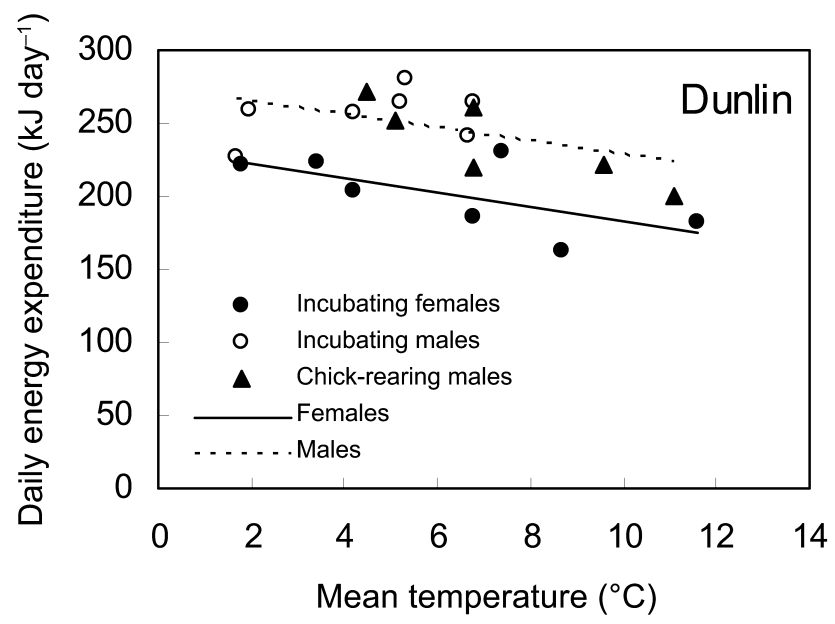

FIG. 2. Daily energy expenditure (DEE) in incubating and chick-rearing Dunlin in relation to mean temperature. The lines represent the significant difference in DEE between males and females. There is no significant difference in DEE between incubation and chick rearing. 
TABLE 1. Multiple regression analysis for brooding and foraging time of adult Little Stints during incubation. $F$ probabilities are for terms sequentially added to the model; estimates (logit proportion of time brooded) are for the final model including all variables.

\begin{tabular}{|c|c|c|c|c|c|}
\hline Variable added & $\mathrm{df}$ & Sum of squares & Variance ratio & $F$ probability & Estimate (logit) \pm SE \\
\hline \multicolumn{6}{|c|}{ Proportion foraging time } \\
\hline Constant & & & & & $-1.872 \pm 0.345$ \\
\hline Age & 1 & 0.5734 & 22.70 & $<0.001$ & $0.1120 \pm 0.0308$ \\
\hline Temperature & 1 & 0.3117 & 12.34 & 0.001 & $0.1333 \pm 0.0395$ \\
\hline Residual & 37 & 0.9688 & & & \\
\hline Total & & 1.8539 & & & \\
\hline \multicolumn{6}{|c|}{ Proportion brooding time } \\
\hline Constant & & & & & $1.8830 \pm 0.4930$ \\
\hline Age & 1 & 0.6628 & 18.14 & $<0.001$ & $-0.1247 \pm 0.0470$ \\
\hline Temperature & 1 & 0.7306 & 20.00 & $<0.001$ & $-0.2349 \pm 0.0622$ \\
\hline Residual & 37 & 1.3830 & & & \\
\hline Total & & 2.7760 & & & \\
\hline
\end{tabular}

$37.3 \pm 15.6 \%$ actually foraging. Parents tending older chicks $(n=$ 12) spent $20.5 \pm 27.7 \%$ of their time brooding and $60.7 \pm 25.9 \%$ foraging. Other activities, including preening, walking, and vigilance, were observed $17 \pm 17.1 \%$ of the time during the first week and $20 \pm 10.9 \%$ thereafter. In addition, there was a tendency for
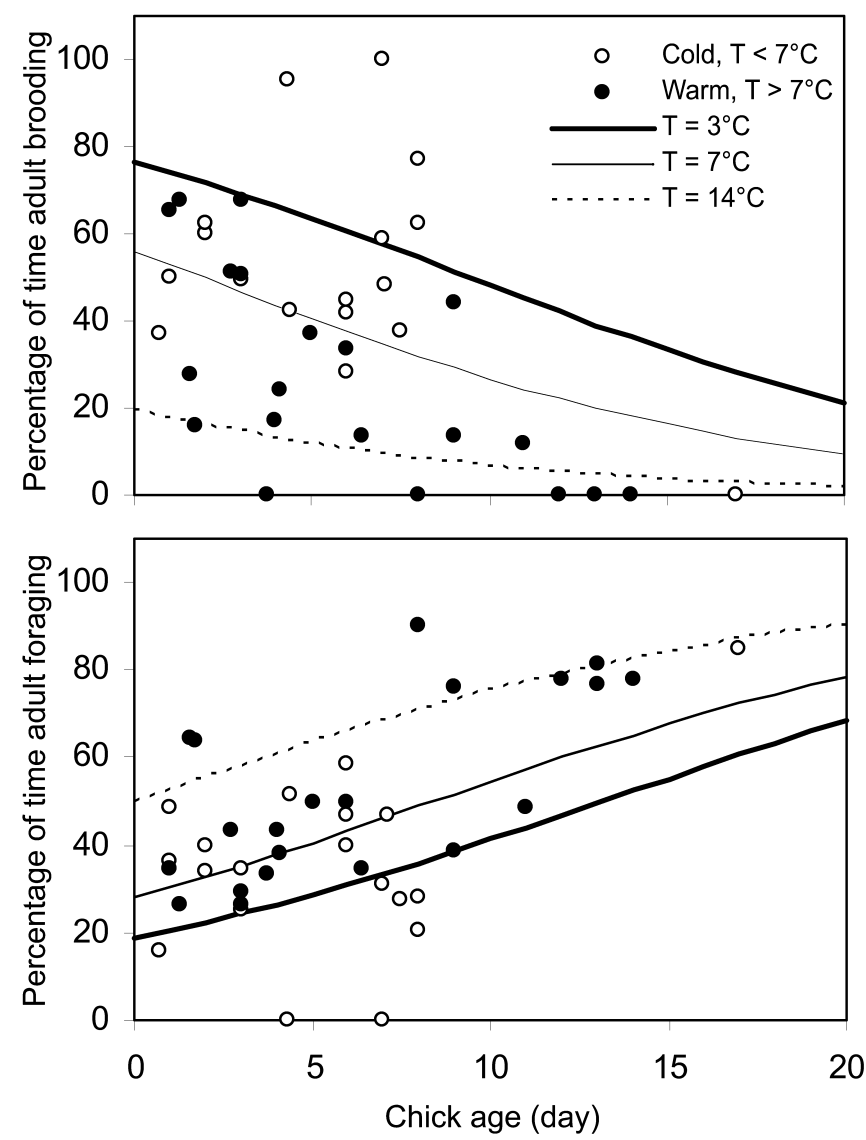

FIG. 3. Percentage of time spent brooding (top) and foraging (bottom) for Little Stints in relation to age (days) and air temperature. The fitted lines are predictions from a logistic regression for the lowest $\left(3^{\circ} \mathrm{C}\right)$, mean $\left(7^{\circ} \mathrm{C}\right)$, and highest $\left(14^{\circ} \mathrm{C}\right)$ air temperatures during observations. brooding time to increase between 2200 and 0400 hours, which indicates a circadian activity rhythm with sleep accommodated into night-time brooding bouts, but this effect was not significant $(P=0.18)$, possibly as a consequence of the smaller sample size for night than for day. Interactions between age, temperature, and "night" did not significantly affect brooding proportions (all $P>$ $0.05)$, nor did additional effects of wind $(P=0.36)$ or rainfall $(P=$ $0.22)$ in a model containing age and temperature.

Calculated from the relationship between total recess time and mean temperature from Tulp and Schekkerman (2006), incubating Little Stints spend, on average, $4.0 \mathrm{~h}$ per day foraging during incubation. In the chick-rearing period, parents with five-day-old chicks spend an estimated $11.5 \mathrm{~h}$ per day foraging. The required net intake rate while foraging is $10.7 \mathrm{~J} \mathrm{~s}^{-1}$ during the incubation period (Table 2). In the chick phase, this drops to $3.6 \mathrm{~J} \mathrm{~s}^{-1}$ because of a much longer potential feeding time.

\section{Discussion}

Daily energy expenditure in Arctic-breeding shorebirds.-On the basis of the allometric relationship between DEE and body mass in incubating and chick-rearing birds derived by Tatner and Bryant (1993), DEE is predicted to be $99.5 \mathrm{~kJ} \mathrm{day}^{-1}$ for incubating and 118.9 $\mathrm{kJ} \mathrm{day}^{-1}$ for chick-rearing Little Stints. For Dunlin, these predictions are $164.3 \mathrm{~kJ} \mathrm{day}^{-1}$ and $134.3 \mathrm{~kJ} \mathrm{day}^{-1}$, respectively. The measured values exceed the allometric predictions by $34-55 \%$ (Little Stint) and $39-77 \%$ (Dunlin). However, this predictive equation is based on temperate-breeding birds only, mainly passerines. The higher DEE measured in the present study is consistent with the finding that DEE is $~ 50 \%$ higher in birds breeding in the Arctic than at temperate latitudes (Tinbergen and Williams 2002). Compared with the regression equation relating DEE to body mass in Arctic-breeding shorebirds (Piersma et al. 2003), our value for Little Stint is $9 \%$ lower $\left(149.2 \mathrm{~kJ} \mathrm{day}^{-1}\right.$, excluding the three Cape Sterlegov points that were included in the allometric prediction, vs. a predicted $164.8 \mathrm{~kJ} \mathrm{day}^{-1}$ ). The value for Dunlin fits very well ( $2 \%$ higher) with the regression equation. The lower value for Little Stint is likely caused by the difference in ambient temperature associated with nearly two degrees latitudinal difference between the study sites (see also Fig. 1). Piersma et al. (2003) did not 
TABLE 2. Overview of the mean daily energy expenditure (DEE), actual foraging time throughout the day, and the required intake rate during foraging to balance the energy budget in Little Stint. Values are given for incubation and chick rearing.

\begin{tabular}{|c|c|c|c|c|c|c|c|c|}
\hline & \multicolumn{4}{|c|}{ Incubation } & \multicolumn{4}{|c|}{ Chick rearing } \\
\hline & Mean \pm SD & $n$ & Minimum & Maximum & Mean \pm SD & $n$ & Minimum & Maximum \\
\hline $\operatorname{DEE}\left(\mathrm{J} \mathrm{s}^{-1}\right)$ & $1.81 \pm 0.09$ & 72 & 1.53 & 2.03 & $1.72 \pm 0.12$ & 72 & 1.31 & 1.88 \\
\hline Feeding time $\left(\mathrm{h} \mathrm{day}^{-1}\right)$ & $4.04 \pm 0.50$ & 72 & 3.53 & 4.44 & $11.48 \pm 3.22$ & 72 & 6.72 & 20.43 \\
\hline Required intake rate $\left(\mathrm{J} \mathrm{s}^{-1}\right)$ & $10.74 \pm 0.10$ & 72 & 10.38 & 10.96 & $3.59 \pm 1.25$ & 72 & 1.54 & 6.72 \\
\hline
\end{tabular}

account for variation in temperature during the DEE measurements, but temperature was the most important variable explaining intraspecific variation in DEE in our study (see also Reid et al. 2000, Weathers et al. 2002).

Daily energy expenditure in Dunlin.-In Dunlin, DEE was significantly higher in males than in females (Fig. 2), despite the males' smaller size. This difference may reflect the extra costs associated with aerial and song display that males perform during the incubation period. Territorial behavior is less prominent after hatching (Cramp and Simmons 1983), but whether the intensity of these displays remains constant or is reduced during incubation is not well known. An alternative explanation might be that male Dunlin have a more intense molt during incubation than females. Both males and females start molting their primaries early in incubation and finish close to departure in autumn (Kania 1990, Tulp and Schekkerman 2001). However, there was no effect of sex on the development of primary molt score in data collected in our study area (logistic regression, date: $P<0.001$, sex: nonsignificant; $n=36$ females, $n=46$ males; I. Tulp and H. Schekkerman unpubl. data). Furthermore, an unequal division of incubation shifts over day and night could lead to a higher DEE in males if they incubate mainly during the day. Their off-duty period would then be in the coldest part of the day, with lower temperatures and, therefore, higher energy expenditure during their feeding recess. This reasoning holds only if the energetic cost of sitting is less than that of foraging during incubation, an assumption that has some empirical validation (Piersma et al. 2003). Such unequal division, with males incubating predominantly during the day, has been demonstrated in the Baltic region (Heldt 1966, Soikkeli 1974), but it has not been investigated in the Arctic. Our captures of males and females did not indicate an unequal division of day and night shifts between the sexes. The proportion of males in captures made before 1800 hours $(n=48)$ was $60 \%$, compared with $50 \%$ after 1800 hours $(n=28)$. Alternatively, in contrast to findings in Alaska that incubation shifts are equally long in both sexes (Norton 1972, Cresswell et al. 2003), they may have differed in length in Taimyr Dunlin, but we have no observations to test this possibility.

Daily energy expenditure unrelated to phase of breeding.Daily energy expenditure did not differ between the incubation and chick-rearing periods in either species. For each phase, DEE is a compound result of both the proportion of time spent on different activities and the energy expenditure associated with each activity. Incubating a clutch at ambient temperatures below the thermoneutral zone increases energy expenditure (Tinbergen and Williams 2002), but foraging on the open, windswept Arctic tundra is even more expensive than incubating in a sheltered nest-cup (Piersma et al. 2003, Cresswell et al. 2004). The costs of incubation may, therefore, be more than offset by the increase in exposure and activity of adult birds during the brood-rearing phase. On the other hand, weather in the Arctic is generally more benign during the chick-rearing period, which reduces thermoregulatory costs. Mean temperature over the three years was $3.3^{\circ} \mathrm{C}$ and $2.8^{\circ} \mathrm{C}$ for Little Stint and Dunlin, respectively, during incubation, and $7.0^{\circ} \mathrm{C}$ and $6.5^{\circ} \mathrm{C}$, respectively, during chick rearing. In our study system, these counteracting effects apparently balanced out, producing a similar overall energy expenditure in both stages of the breeding cycle.

In a study in which DEE during incubation was compared with that during chick rearing (Tatner and Bryant 1993), differences between the two stages were found in only 5 of 16 bird species. In these species, all of which feed their (altricial and semiprecocial) chicks, DEE was larger during brood rearing. No difference in DEE during the two stages of incubation was found in the biparental Common Sandpiper (Actitis hypoleucos), which has precocial young. Considering previous studies reported in Tatner and Bryant (1993) and Tinbergen and Williams (2002) along with our own data, the average ratio between DEE in the two phases for adults with self-feeding chicks (Little Stint, Dunlin, and Common Sandpiper) is identical (mean $=1.20 \pm 0.23 ; n=3$ ) to the ratio for adults that provision their young (mean $=1.16 \pm 0.09 ; n=18$ ). Clearly, we need substantially more field estimates of energy expenditure in birds tending precocial chicks before we can draw conclusions about the validity of the hypothesis that this developmental mode, compared with (semi)altricial development, reduces parental energy demands for chick rearing.

Combining energy expenditure and foraging time.-Although there was no difference in mean DEE between stages of the breeding cycle, the time and energy budgets, along with our estimates of required intake rate, suggest that the incubation phase is the most energetically demanding phase of the breeding season for the uniparental Little Stint. This was caused by an almost threefold increase in foraging time from incubation to chick rearing. Although we lack field data on the time budgets of Dunlin in our study site that would allow a similar calculation for this species, it is very likely that the shared incubation of Dunlin will increase potential feeding time and, hence, reduce the required intake rate in Dunlin compared with that in Little Stint. Assuming that both sexes contribute equally to incubation in Dunlin (Cresswell et al. 2003) and that the time budget in the chick period is similar to that in Little Stint, estimates of $\mathrm{IR}_{\mathrm{f}}$ for male Dunlin would be $\sim 5 \mathrm{~J} \mathrm{~s}^{-1}$ during incubation and $\sim 8 \mathrm{~J} \mathrm{~s}^{-1}$ during chick rearing. Because the slightly larger chicks of Dunlin probably require less brooding than young Little Stints (Visser and Ricklefs 1993a, b), this may 
somewhat overestimate $\mathrm{IR}_{\mathrm{f}}$ during brood rearing, and energetic demands on male Dunlin may be similar in the two phases.

The idea that incubation is energetically more demanding and, at times, stressful for uniparental incubators is corroborated by body-mass dynamics in our two study species. Arctic shorebirds generally maintain higher body mass during incubation than during chick rearing as an insurance against starvation (Soloviev and Tomkovich 1997, Tulp et al. 2002), but a gradual decrease in mass in the course of the incubation period was not observed in either Little Stint or Dunlin. This indicates that under normal conditions, DEE is not fueled from energy stores accumulated before breeding (i.e., they are "income" breeders and not "capital" breeders; Klaassen et al. 2001, contra Drent et al. 2007). However, Little Stints show a decrease in body mass in response to several consecutive days of adverse weather (Tulp and Schekkerman 2006). Evidently, they cannot balance their energy budget in such cold conditions as a result of reduced food availability or elevated energy expenditure, even though they spend more time off the nest. The lack of a similar response to weather in Dunlin (Tulp and Schekkerman 2006) indicates that for biparental incubators, feeding time during incubation is less limiting. Another indication that energetic demands on uniparentals during incubation can be problematically high is that in 2000-2002, 19 of 331 nests were deserted by Little Stints, compared with only 1 of 91 nests in Dunlin $\left(\chi^{2}=3.41, P=0.06\right.$; Schekkerman et al. 2004).

Very few studies have made a comparison of (required) intake rates between the phases of the breeding cycle in birds. Custer et al. (1986) measured energy budgets and intake rates in Lapland Longspur (Calcarius lapponicus), an Arctic passerine in which the female incubates and both parents feed the chicks. In this species, DEE in both sexes was rather similar between the phases, but the highest required foraging intake rate occurred in the nestling phase for both males and females. Tinbergen and Williams (2002) reviewed published data on energy expenditure in breeding birds and estimated that, in general, intake rates in the incubation phase must be about twice as high as in the nestling phase for birds that incubate without assistance from their mates, but of the same magnitude in species with shared incubation. Our data conform to this pattern.

The timing of breeding in birds often coincides with a seasonal maximum in the availability of food for the chicks (Lack 1950) but may additionally be shaped by nutritional stress earlier in the egg-laying period (Perrins 1970), by the minimization of energetic demands of parents during either incubation or chick rearing, or even by future reproductive potential (Brinkhof et al. 2002, Hanssen et al. 2005). Differences in time-energy budgets during incubation and chick rearing may be an important factor determining the required level of food availability and, hence, the timing of reproduction. Early breeding is generally favorable for the chicks, if hatching then coincides with the peak in food supply. However, especially for uniparental incubators, food availability during incubation may constrain early breeding (Drent 2006). Indeed, in our study area, Little Stints start breeding later than Dunlin, in accordance with a general pattern whereby shorebird species with uniparental incubation tend to breed later than biparental incubators (Whitfield and Tomkovich 1996). Thus, various optimality rules with respect to timing of breeding may apply for species with differing breeding strategies.

\section{ACKNOWLEDGMENTS}

The expeditions in 2000-2002 were financed through the research program North-South (DWK 404) of the Dutch Ministry of Agriculture and Nature Management and Food Safety. The following organizations and persons assisted in organizing the expeditions: the staff of the Great Arctic Reserve, G. Boere, B. Ebbinge, P. Tomkovich, G. Müskens, S. Kharitonov, the Dudko family, and A. Beliashov. B. Verstappen (CIO) performed the isotope analyses. We thank K. Tjörve, R. Klaassen, O. Langevoord, J. de Leeuw, L. Peters, and O. Stepanova for help collecting the data. I.T. received research grants from Nederlandse Organisatie voor Wetenschappelijk Onderzoek (2000) and from the European Science Foundation (2001). We appreciate comments by B. Ens, S. R. McWilliams, S. G. Sealy, and one anonymous reviewer on an earlier version of the manuscript.

\section{Literature Cited}

Brinkhof, M. W. G., A. J. Cave, S. Daan, and A. C. Perdeck. 2002. Timing of current reproduction directly affects future reproductive output in European Coots. Evolution 56:400-411.

BRYANT, D. M., AND P. TATNER. 1991. Intraspecies variation in avian energy expenditure: Correlates and constraints. Ibis 133:236245.

Cartar, R. V., And R. D. Montgomerie. 1987. Day-to-day variation in nest attentiveness of White-rumped Sandpipers. Condor 89:252-260.

Chernov, Y. I. 1985. The Living Tundra. Cambridge University Press, Cambridge, United Kingdom.

Cramp, S., And K. E. L. Simmons. 1983. The Birds of the Western Palearctic, vol. 3. Oxford University Press, Oxford, United Kingdom.

Cresswell, W., S. Holt, J. M. Reid, D. P. Whitfield, and R. J. Mellanby. 2003. Do energetic demands constrain incubation scheduling in a biparental species? Behavioral Ecology 14:97102.

Cresswell, W., S. Holt, J. M. Reid, D. P. Whitfield, R. J. MelLANBY, D. NorTON, AND S. WALDRON. 2004. The energetic costs of egg heating constrain incubation attendance but do not determine daily energy expenditure in the Pectoral Sandpiper. Behavioral Ecology 15:498-507.

Custer, T. W., R. G. Osborn, F. A. Pitelka, and J. A. Gessaman. 1986. Energy budget and prey requirements of breeding Lapland Longspurs near Barrow, Alaska, U.S.A. Arctic and Alpine Research 18:415-427.

DE HEIJ, M. E. 2006. Costs of avian incubation. How fitness, energetics and behaviour impinge on the evolution of clutch size. Ph.D. dissertation, University of Groningen, The Netherlands.

Drent, R. H. 2006. The timing of birds' breeding seasons: The Perrins hypothesis revisited especially for migrants. Ardea 94: 305-322.

Drent, R. H., AND S. DAAn. 1980. The prudent parent: Energetic adjustments in avian breeding. Ardea 68:225-252.

Drent, R. H., G. Eichorn, A. Flagstad, A. J. Van der Graaf, K. E. Litvin, AND J. StAhl. 2007. Migratory connectivity in Arctic Geese: Spring stopovers are weak links in meeting targets for breeding. Journal of Ornithology 148 (Supplement 2):S501-S514. 
Gessaman, J. A., And K. A. NAgy. 1988. Energy metabolism: Errors in gas-exchange conversion factors. Physiological Zoology 61:507-513.

Hanssen, S. A., D. Hasselquist, I. Folstad, and K. E. ERikstad. 2005. Cost of reproduction in a long-lived bird: Incubation effort reduces immune function and future reproduction. Proceedings of the Royal Society of London, Series B 272:1039-1046.

Heldt, R. 1966. Zur Brutbiologie des Alpenstrandläufers. Corax 1: 173-188.

HildÉn, O. 1978. Occurrence and breeding biology of the Little Stint Calidris minuta in Norway. Anser (Supplement 3):96-100.

KaniA, W. 1990. The primary moult of breeding Dunlins Calidris alpina in the central Taymyr in 1989. Wader Study Group Bulletin 60:17-19.

Klaassen, M., Å. Lindström, H. Meltofte, and T. Piersma. 2001. Arctic waders are not capital breeders. Nature 413:794.

LACK, D. 1950. The breeding seasons of European birds. Ibis 92: 288-316.

Lifson, N., AND R. MCCLintock. 1966. Theory of use of the turnover rates of body water for measuring energy and material balance. Journal of Theoretical Biology 12:46-74.

NorTON, D. W.1972. Incubation schedules of four species of calidridine sandpipers at Barrow, Alaska. Condor 74:164-176.

Perrins, C. M. 1970. The timing of birds' breeding seasons. Ibis 112:242-255.

Piersma, T., Å. Lindström, R. H. Drent, I. Tulp, J. Jukema, R. I. G. Morrison, J. Reneerkens, H. ScheKkerman, and G. H. VISSER. 2003. High daily energy expenditure of incubating shorebirds on High Arctic tundra: A circumpolar study. Functional Ecology 17:356-362.

Prater, A. J., J. H. Marchant, and J. Vuorinen. 1977. Guide to the Identification and Ageing of Holarctic Waders. British Trust for Ornithology, Tring, United Kingdom.

Reid, J. M., P. Monaghan, and G. D. Ruxton. 2000. Resource allocation between reproductive phases: The importance of thermal conditions in determining the cost of incubation. Proceedings of the Royal Society of London, Series B 267:37-41.

RiCKLEFS, R. E. 1974. Energetics of reproduction in birds. Pages 152 297 in Avian Energetics (R. A. Payner, Jr., Ed.). Publications of the Nutall Ornithological Club, no. 15.

Schekkerman, H., I. Tulp, K. M. Calf, and J. J. de Leeuw. 2004. Studies on breeding shorebirds at Medusa Bay, Taimyr, in summer 2002. Alterra-report 922. Alterra, Wageningen, The Netherlands.

SoIKKELI, M. 1974. Size variation of breeding Dunlins in Finland. Bird Study 21:151-154.

Soloviev, M. Y., AND P. S. Toмкоvich. 1997. Body mass changes in waders (Charadrii) in a High Arctic area at northern Taimyr, Siberia. Journal für Ornithologie 138:271-281.

Speakman, J. R. 1997. Doubly Labelled Water: Theory and Practice. Chapman and Hall, London.
TATner, P., AND D. M. BRYANT. 1993. Interspecific variation in daily energy expenditure during avian incubation. Journal of Zoology (London) 231:215-232.

Tinbergen, J. M., AND J. B. Williams. 2002. Energetics of incubation. Pages 299-313 in Avian Incubation: Behaviour, Environment and Evolution (D. C. Deeming, Ed.). Oxford University Press, Oxford, United Kingdom.

Tulp, I., AND H. ScheKkerman. 2001. Studies on breeding shorebirds at Medusa Bay, Taimyr, in summer 2001. Alterra-report 415. Alterra, Wageningen, The Netherlands.

Tulp, I., And H. ScheKkerman. 2006. Time allocation between feeding and incubation in uniparental Arctic-breeding shorebirds: Energy reserves provide leeway in a tight schedule. Journal of Avian Biology 37:207-218.

Tulp, I., H. Schekkerman, P. Chylarecki, P. Tomkovich, M. Soloviev, L. Bruinzeel, K. Van DijK, O. Hildén, H. HötKER, W. KANIA, AND OTHERS. 2002. Body mass patterns of Little Stints at different latitudes during incubation and chick-rearing. Ibis 144:122-134.

TulP, I. 2007. The arctic pulse. Timing of breeding in long-distance migrant shorebirds. Ph.D. dissertation, University of Groningen, The Netherlands.

Visser, G. H., AND R. E. RickLefs. 1993a. Development of temperature regulation in shorebirds. Physiological Zoology 66:771792.

Visser, G. H., AND R. E. RiCKLEFS. 1993b. Temperature regulation in neonates of shorebirds. Auk 110:445-457.

Visser, G. H., and H. ScheKkerman. 1999. Validation of the doubly labeled water method in growing precocial birds: The importance of assumptions concerning evaporative water loss. Physiological and Biochemical Zoology 72:740-749.

Williams, J. B. 1996. Energetics of avian incubation. Pages 375415 in Avian Energetics and Nutritional Ecology (C. Carey, Ed.). Chapman and Hall, New York.

Weathers, W. W., C. L. Davidson, C. R. Olson, M. L. Morton, N. NuR, AND T. R. FAMULA. 2002. Altitudinal variation in parental energy expenditure by White-crowned Sparrows. Journal of Experimental Biology 205:2915-2924.

Weathers, W. W., AND K. A. Sullivan. 1993. Seasonal patterns of time and energy allocation by birds. Physiological Zoology 66:511-536.

Webster, M. D., AND W. W. WeAthers. 1989. Validation of singlesample doubly labeled water method. American Journal of Physiology 256:R572-R576.

Whitfield, D. P., AND P. S. TomKovich. 1996. Mating system and timing of breeding in Holarctic waders. Biological Journal of the Linnean Society 57:277-289.

Associate Editor: S. R. McWilliams 
APPENDIX 1. Daily energy expenditure (DEE) of Little Stints during the incubation and chick-rearing phases. Negative days to hatching means days before hatching, whereas positive values represent ages of chicks. Birds \#01, \#04, and \#10 were measured at a different study site at Cape Sterlegov in 1994 (Piersma et al. 2003). TBW = total body water; birds for which "no initial" is mentioned under TBW were subjected to the single-sample protocol.

\begin{tabular}{|c|c|c|c|c|c|c|c|c|c|}
\hline ID & $\begin{array}{l}\text { Wing } \\
\text { length } \\
(\mathrm{mm})\end{array}$ & $\begin{array}{c}\text { Start of } \\
\text { measurement }\end{array}$ & $\begin{array}{c}\text { Chicks } \\
(n)\end{array}$ & $\begin{array}{l}\text { Duration } \\
\text { (h) }\end{array}$ & $\begin{array}{c}\text { Days to } \\
\text { hatching or } \\
\text { age of chicks } \\
\text { (days) }\end{array}$ & $\begin{array}{c}\text { Mean body } \\
\text { mass (g) }\end{array}$ & $\begin{array}{c}\text { Mean } \\
\text { temperature } \\
\left({ }^{\circ} \mathrm{C}\right)\end{array}$ & $\begin{array}{c}\text { DEE } \\
\left(k^{\left.d a y^{-1}\right)}\right.\end{array}$ & TBW (\%) \\
\hline \multicolumn{10}{|c|}{ Incubating } \\
\hline FS08202 & 97 & 26 June 1996 & & 23.9 & -15 & 28.4 & 4.6 & 144.3 & No initial \\
\hline FS08205 & 99 & 24 June 1996 & & 23.9 & -19 & 24.7 & 3.5 & 164.2 & No initial \\
\hline FS08207 & 94 & 26 June 1996 & & 24.5 & -13 & 27.9 & 4.6 & 145.2 & 67.9 \\
\hline FS08209 & 95 & 27 June 1996 & & 23.9 & -16 & 32.0 & 4.8 & 159.0 & 60.8 \\
\hline FS08210 & 95 & 29 June 1996 & & 24.4 & -13 & 27.7 & 2.6 & 145.2 & 66.8 \\
\hline FS08215 & 97 & 4 July 1996 & & 24.8 & -10 & 28.3 & 3.2 & 154.7 & 63.0 \\
\hline FS08218 & 97 & 3 July 1996 & & 25.5 & -15 & 27.0 & 3.1 & 159.0 & No initial \\
\hline FS08220 & 96 & 6 July 1996 & & 28.1 & -8 & 29.9 & 3.4 & 134.8 & No initial \\
\hline FS08224 & 98 & 30 June 1996 & & 24.4 & -14 & 29.2 & 5.4 & 156.4 & No initial \\
\hline FS08231 & 98 & 3 July 1996 & & 25.4 & -17 & 26.4 & 3.1 & 165.0 & No initial \\
\hline FS08232 & 99 & 5 July 1996 & & 24.1 & -16 & 27.1 & 4.2 & 129.6 & 70.0 \\
\hline FS08233 & 100 & 5 July 1996 & & 24.9 & -17 & 28.1 & 4.2 & 129.6 & No initial \\
\hline FS08251 & 100 & 6 July 1996 & & 25.3 & -18 & 31.8 & 3.4 & 159.0 & No initial \\
\hline FS08256 & 101 & 8 July 1996 & & 23.8 & -9 & 31.0 & 6.2 & 141.7 & 57.5 \\
\hline FS08257 & 102 & 8 July 1996 & & 24.0 & -17 & 27.7 & 6.2 & 127.9 & 69.4 \\
\hline FS08258 & 95 & 8 July 1996 & & 24.2 & -6 & 30.9 & 6.2 & 129.6 & No initial \\
\hline FS08259 & 100 & 9 July 1996 & & 25.1 & -1 & 27.8 & 4.5 & 171.1 & No initial \\
\hline FS10710 & 97 & 29 June 2001 & & 24.8 & -14 & 25.7 & 3.2 & 169.9 & 65.4 \\
\hline \#01 & 102 & 9 July 1994 & & 21.4 & $?$ & 30.2 & 12.9 & 181.8 & 63.3 \\
\hline \#04 & 96 & 16 July 1994 & & 24.2 & -11 & 29.0 & 0.6 & 203.1 & 72.2 \\
\hline$\# 10$ & 104 & 26 July 1994 & & 22.9 & -1 & 28.8 & 0.3 & 169.4 & 71.9 \\
\hline Average $\pm \mathrm{SE}$ & & & & & & & & $154.3 \pm 4.2$ & $66 \pm 1.0$ \\
\hline \multicolumn{10}{|c|}{ Chick rearing } \\
\hline FS10037 & 95 & 13 July 2000 & 4 & 24.7 & 1 & 24.8 & 1.2 & 227.2 & 71.3 \\
\hline FS10033 & 97 & 19 July 2000 & 4 & 23.3 & 3 & 27.4 & 1.58 & 193.2 & 65.2 \\
\hline FS10088 & 95 & 20 July 2000 & 3 & 24.1 & 1 & 22.1 & 2.71 & 152.8 & 75.7 \\
\hline FS10089 & 102 & 22 July 2000 & 4 & 24.6 & 1 & 31.2 & 8.5 & 140.5 & 65.2 \\
\hline FS10039 & 99 & 25 July 2000 & 4 & 26.5 & 7 & 31.1 & 9.86 & 170.8 & 64.0 \\
\hline FS10047 & 101 & 25 July 2000 & 4 & 24.6 & 6 & 27.1 & 9.81 & 151.6 & 68.1 \\
\hline FS10050 & 98 & 27 July 2000 & 4 & 24.8 & 1 & 27.0 & 6 & 134.2 & 63.2 \\
\hline FS10096 & 98 & 28 July 2000 & 4 & 25.1 & 4 & 27.7 & 7.99 & 142.1 & 66.4 \\
\hline KS06151 & 101 & 30 July 2000 & 3 & 24.4 & 2 & 28.7 & 7.21 & 201.6 & 66.8 \\
\hline KS06153 & 104 & 30 July 2000 & 4 & 23.9 & 2 & 28.2 & 7.17 & 140.2 & 64.1 \\
\hline KS06152 & 102 & $\begin{array}{l}31 \text { July } 2000 \\
1 \text { August }\end{array}$ & 4 & 24.8 & 5 & 27.6 & 7.6 & 142.8 & 68.8 \\
\hline $\begin{array}{l}\text { KS06246 } \\
\text { Average } \pm \text { SE }\end{array}$ & 102 & 2000 & 2 & 24.7 & 5 & 30.7 & 16.43 & $\begin{array}{c}121.5 \\
159.9 \pm 9.2\end{array}$ & $\begin{array}{c}63.5 \\
66.9 \pm 1.1\end{array}$ \\
\hline Overall average \pm SE & & & & & & & & $156.3 \pm 4.2$ & $66.5 \pm 0.7$ \\
\hline
\end{tabular}


APPENDIX 2. Daily energy expenditure (DEE) in Dunlin during the incubation and chick-rearing phases. Negative days to hatching indicate days before hatching, and positive values represent ages of chicks. TBW = total body water; birds for which "no initial" is mentioned under TBW were subjected to the single-sample protocol.

\begin{tabular}{|c|c|c|c|c|c|c|c|c|c|c|c|}
\hline ID & Sex & $\begin{array}{c}\text { Age } \\
\text { (calendar } \\
\text { year) }\end{array}$ & $\begin{array}{c}\text { Wing } \\
\text { length } \\
(\mathrm{mm})\end{array}$ & $\begin{array}{c}\text { Start of } \\
\text { measurement }\end{array}$ & $\begin{array}{c}\text { Chicks } \\
(n)\end{array}$ & $\begin{array}{l}\text { Duration } \\
\text { (h) }\end{array}$ & $\begin{array}{c}\text { Days to } \\
\text { hatching or } \\
\text { age of chicks } \\
\text { (days) }\end{array}$ & $\begin{array}{c}\text { Mean } \\
\text { body mass } \\
(\mathrm{g})\end{array}$ & $\begin{array}{c}\text { Mean } \\
\text { temperature } \\
\left({ }^{\circ} \mathrm{C}\right)\end{array}$ & DEE $\left(k J\right.$ day $\left.^{-1}\right)$ & TBW (\%) \\
\hline \multicolumn{12}{|c|}{ Incubating } \\
\hline KS06326 & $\mathrm{F}$ & $>2$ & 120 & 3 July 2002 & & 24 & -2 & 51.5 & 8.66 & 162.3 & 68.0 \\
\hline KS06353 & M & $>2$ & 119 & 5 July 2002 & & 24 & -3 & 51.0 & 1.97 & 258.1 & 66.6 \\
\hline KS06354 & $\mathrm{F}$ & $>2$ & 121 & 6 July 2002 & & 32 & -6 & 54.3 & 1.81 & 221.6 & No initial \\
\hline KS07204 & M & 2 & 114 & 7 July 2002 & & 25 & -1 & 52.1 & 6.67 & 241.4 & 64.8 \\
\hline KS06355 & $\mathrm{F}$ & $>2$ & 125 & 7 July 2002 & & 23 & -3 & 56.3 & 7.37 & 230.9 & 68.9 \\
\hline KS06358 & $\mathrm{F}$ & $>2$ & 121 & 8 July 2002 & & 24 & -2 & 54.8 & 3.39 & 223.7 & 59.9 \\
\hline KS06363 & M & 2 & 115 & 10 July 2002 & & 23 & -3 & 46.4 & 1.68 & 227.6 & 68.9 \\
\hline KSO6364 & M & $>2$ & 119 & 11 July 2002 & & 25 & -3 & 54.7 & 5.21 & 264.4 & No initial \\
\hline KS06365 & M & 2 & 119 & 11 July 2002 & & 25 & -11 & 49.5 & 5.34 & 279.9 & No initial \\
\hline KS07235 & $\mathrm{F}$ & $>2$ & 118 & 1 July 2001 & & 25 & -12 & 59.2 & 4.2 & 203.3 & 61.6 \\
\hline KS07236 & M & $>2$ & 118 & 1 July 2001 & & 24 & -10 & 54.0 & 4.2 & 256.7 & 67.3 \\
\hline KS07242 & $\mathrm{F}$ & $>2$ & 116 & 6 July 2001 & & 25 & -9 & 52.6 & 11.6 & 182.2 & 68.7 \\
\hline KS06106 & $\mathrm{F}$ & $>2$ & 122 & 8 July 2001 & & 25 & -9 & 52.9 & 6.8 & 185.4 & No initial \\
\hline $\begin{array}{l}\text { KS07236 } \\
\text { Average } \pm \text { SE }\end{array}$ & M & $>2$ & 118 & 8 July 2001 & & 48 & -5 & 51.4 & 6.8 & $\begin{array}{c}264.5 \\
228.7(9.4)\end{array}$ & $\begin{array}{l}\text { No initial } \\
66.1(0.9)\end{array}$ \\
\hline \multicolumn{12}{|c|}{ Chick rearing } \\
\hline KS07237 & M & $>2$ & 117 & 6 July 2001 & 4 & 48 & 0 & 51.5 & 11.1 & 199.7 & 65.6 \\
\hline KS07446 & M & $>2$ & 117 & 8 July 2001 & 4 & 25 & 3 & 50.8 & 6.8 & 220.3 & No initial \\
\hline KSO6204 & M & 2 & 114 & 17 July 2001 & 4 & 24 & 1 & 44.3 & 6.8 & 260.1 & 71.1 \\
\hline KS07454 & M & $>2$ & 116 & 18 July 2001 & 3 & 25 & 3 & 46.8 & 5.1 & 251.1 & No initial \\
\hline KS07459 & M & $>2$ & 116 & 19 July 2001 & 4 & 25 & 2 & 47.5 & 4.5 & 272.3 & No initial \\
\hline $\begin{array}{l}\text { KS07471 } \\
\text { Average } \pm \text { SE }\end{array}$ & M & $>1$ & 114 & 23 July 2001 & 3 & 25 & 3 & 42.5 & 9.6 & $\begin{array}{c}222.3 \\
237.6 \pm 11.3\end{array}$ & $\begin{array}{c}70.9 \\
69.2 \pm 1.3\end{array}$ \\
\hline Overall averag & $\pm \mathrm{SE}$ & & & & & & & & & $231.4 \pm 7.3$ & $66.9 \pm 0.8$ \\
\hline
\end{tabular}

